\title{
Między historiq a pamięciq.
}

Wspomnienia i pamiętniki

w zbiorach biblioteki Ośrodka

Badań Naukowych

im. Wojciecha Kętrzyńskiego

w Olsztynie (cz. 1)

opracowanie:

\section{ALICJA DOBROSIELSKA}

Ośrodek Badań Naukowych im. Wojciecha Kętrzyńskiego w Olsztynie

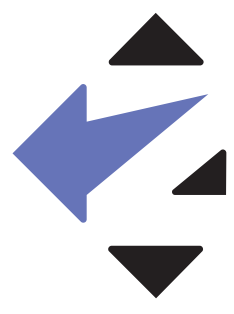




\section{Wstęp}

W Zbiorach Specjalnych Biblioteki Ośrodka Badań Naukowych im. Wojciecha Kętrzyńskiego w Olsztynie znajduje się obszerny zbiór wspomnień i pamiętników. Są to zarówno autorskie wielostronicowe relacje o zdarzeniach, których autorzy byli uczestnikami bądź naocznymi świadkami, jak też prowadzone i spisywane od dzieciństwa kilkustronicowe wspomnienia. Niemały zbiór stanowią prace napisane na konkretny temat i nadesłane na konkursy organizowane przez OBN i Olsztyński Oddział Polskiego Towarzystwa Historycznego (od 1947 r.), a także wywiady i ankiety zawierające wspomnienia.

Pamiętniki i wspomnienia zgromadzone przez bibliotekę OBN do 1985 r. opisał Zbigniew Fras w pracy Materiały pamiętnikarskie w zbiorach Ośrodka Badań Naukowych im. Wojciecha Kętrzyńskiego'. Przywołana publikacja liczy 148 ponumerowanych stron, zawarty tu szczegółowy katalog pamiętników i wspomnień opatrzono kilkustronicowym wstępem, indeksami: osobowym, nazw geograficznych, rzeczowym, całość zamyka spis treści. Przedmiotem zainteresowania Frasa były „rękopisy zawierające informacje z przeszłości danej osoby, wiadomości o instytucjach społeczno-kulturalnych, politycznych, miejscowościach czy ważnych wydarzeniach, w których autor brał czynny udział lub był ich świadkiem”2. Spośród materiałów opisanych przez autora w bibliotece pozostała już tylko część zbiorów oznaczona sygnaturą R, materiały z sygnaturami PTH-R zostały przekazane do Archiwum Państwowego w Olsztynie jako integralna część Oddziału Olsztyńskiego Polskiego Towarzystwa Historycznego (dalej: OO PTH).

Celem niniejszego artykułu jest uzupełnienie inwentarza Frasa o wspomnienia i materiały pamiętnikarskie zgromadzone po 1985 r., dotyczące Kresów Wschodnich, doświadczenia II wojny światowej oraz szkolnictwa na Warmii i Mazurach w okresie międzywojennym i po II wojnie światowej. W zbiorach biblioteki znajduja się zarówno teksty będące uzupełnieniem wcześniej nadesłanych relacji ${ }^{3}$, autorskie wspomnienia związane ze szkolnictwem polskim na terenie dzisiejszego województwa warmińsko-mazurskiego ${ }^{4}, \mathrm{w}$ tym również spisane na drukach ankiet rozsyłanych przez OBN do szkół ${ }^{5}$. Odrębną grupę materiałów pamiętnikarskich stanowią teksty nadesłane na konkurs „Dać świadectwo prawdzie”. W roku 1989 OBN i OO PTH wspólnie zorganizowali konkurs na relacje mieszkańców dawnych Kresów

1 Materiały pamiętnikarskie w zbiorach Ośrodka Badań Naukowych im. Wojciecha Kętrzyńskiego, oprac. Z. Fras, „Informator Ośrodka Badań Naukowych im. W. Kętrzyńskiego w Olsztynie”, nr 37, Olsztyn 1986; zob. Z. Januszkiewicz, rec., Materiały pamiętnikarskie w zbiorach Ośrodka Badań Naukowych im. Wojciecha Ketrzyńskiego, oprac. Z. Fras, „Informator Ośrodka Badań Naukowych im. W. Kętrzyńskiego w Olsztynie”, nr 37, Olsztyn 1986, „Komunikaty Mazursko-Warmińskie”, nr 33-36 (1-4 /1989), s. 151-154.

3 Ośrodek Badań Naukowych im. Wojciecha Kętrzyńskiego w Olsztynie (dalej: OBN), Zbiory Specjalne, R-882, 904, 909, 912, 918-920. 
Wschodnich, którzy osiedlili się w ówczesnym województwie olsztyńskim ${ }^{6}$. Materiały te tylko w niewielkiej liczbie zachowały się w formie maszynopisów i rękopisów ${ }^{7}$, a w znacznej części zostały utrwalone na dwóch mikrofilmach ${ }^{8}$. Bezpośrednio z konkursem wiążą się także wspomnienia spisane w oparciu o ankiety przeprowadzone w 1989 r. z mieszkańcami Olsztyna9.

Tekst składa się z trzech części: 1. Uzupełnienia do wcześniej nadesłanych materiałów; 2. Wspomnienia nauczycieli szkół polskich na Warmii i Mazurach; 3. „Dać świadectwo prawdzie" - konkurs i wywiady. W opisie poszczególnych materiałów podaję, podobnie jak Zbigniew Fras, numer inwentarzowy, imię i nazwisko autora, tytuł wspomnień. Wskazuję ponadto czy jest to rękopis, czy maszynopis, jak też czy tekst został już wydany drukiem. Informuję także o formacie, ilości kart lub stron i tomów, jak też klatek w przypadku mikrofilmów oraz o ewentualnych załącznikach w postaci zdjęć, oryginałów czy też kopii dokumentów urzędowych itp. Przy większości poszczególnych wspomnień umieszczam krótkie streszczenia, w których przywołuję najważniejsze treści i osoby przedstawione przez autorki i autorów wspomnień.

\section{Uzupełnienia do wcześniej nadesłanych materiałów}

$\mathrm{R}-882$

Zdzisław Grabowski, rkps, form. A4, ss. 201, ilustr.

Wspomnienia uzupełnione o okres okupacji i czasy powojenne (do lat 80. XX w.) . $^{10}$; listy pisane do Bohdana Koziełło-Poklewskiego w okresie 10 października 1984 30 maja 1985 r.; rok 1939, roboty przymusowe w Niemczech, Orneta, praca przy budowie lotniska, życie obozowe, sabotaże, stosunki rodzinne, działania w ramach grupy operacyjnej AK „Wkra”, socjalizm.

\section{R-904}

Kazimierz Pietrzak-Pawłowski, „Życiorys własny”, mps, ss. 2

Ur. w roku 1904 w Duisburgu; działalność w Związku Polaków w Niemczech, praca w „Społem” w Warszawie, ruch oporu, Okręgowy Polski Komitet Narodowościowy przy Urzędzie Pełnomocnika Rządu RP na Okręg Mazurski, działalność w Polsce Ludowej, docent nauk ekonomicznych, pracownik Spółdzielczego Instytutu Badawczego.

6 Ośrodek Badań Naukowych im. Wojciecha Kętrzyńskiego w latach 1988-1989. Sprawozdanie z działalności, Olsztyn 1990, s. 13.

OBN, Zbiory Specjalne, R-1113, R-1114, R-1115, R-1116, R-1117, R-1118, R-1119. 
R-909

Stefan Niziołek, „Garść wspomnień”, mps, cz. 1, ss. 108 (1986); cz. 2, ss. 150 (1987); cz. 3, ss. 194 (1987), wiersze ${ }^{11}$

Ur. w roku 1899; młynarz, wspomnienia czasów wojny przeplatają się z refleksjami odnośnie do współczesności, lat 70. i 80. XX w.; wspomnienia zebrane w postaci 91 krótkich, kilkustronicowych tekstów; II wojna światowa, działalność w Polsce Ludowej, Olsztyn w roku 1945, sprawy społeczne i bytowe na Mazurach po roku 1945, relacje Niemców i Polaków, młynarstwo i upaństwowienie młynów, okupacja sowiecka, praca w Muzeum Herdera w Morągu.

R-912

Stefan Cendrowski, Rozmowa ze Stefanem Cendrowskim; spisana z taśmy magnetofonowej 23 XI 1985 (ss. 12), 5 III 1987 (ss. 17); nagrania wykonał i sporządził mps Bronisław Sałuda; mps ${ }^{12}$, form. A4

Okupacja, Olsztyn po roku 1945; Witold Witkowski, Władysław Mizielski, Jerzy Burski, Jakub Prawin, Bugajski, Lucjusz Dura; PPS i PPR; powstanie i działalność Państwowego Związku Łowieckiego, sprawy rodzinne; dokumenty: oświadczenie dot. Kazimierza Pietrzaka-Pawłowskiego, że podejmował on działalność konspiracyjną, mps, form. A4, ss. 1; zaświadczenie o działalności konspiracyjnej Władysława Mizielskiego oraz Emilii Mizielskiej, ps. „Mila”; życiorys Władysława Mizielskiego, rkps, form. A4, ss. 2; notatka dot. pracy w szkolnictwie Witolda Witkowskiego, rkps, form. A5, ss. 2; list Witolda Witkowskiego dot. jego pracy zawodowej i społecznej, rkps, form. A4, ss. 2; zaświadczenie dot. Witolda Witkowskiego, iż w czasie II wojny światowej pracował jako nauczyciel i był członkiem Tajnej Organizacji Nauczycielskiej, mps, form. A4, ss. 1; list Witolda Witkowskiego do Związku Bojowników o Wolność i Demokrację, mps, ss. 2.

R-918

Jan Benke, „Życiorys”, mps, form. A4, ss. 12

Zawartość identyczna jak w mpsie PTH R-112³.

R-919

Józef Krebs, „Z wizytą u Józefa Krebsa”, mps, form. A4, ss. 2

Syn Piotra, pochodzący z Rzecka, działacz plebiscytowy, członek Towarzystwa i Związku Polaków w Niemczech, mieszkaniec Biskupca.

R-920

Jan Boenigh, „Alfons Barczewski, pedagog i prawnik”, mps, form. A4, ss. 12

Subiektywny życiorys Alfonsa Barczewskiego, olsztyńskiego pedagoga i prawnika.

11 Lata 1945-1970 opisał autor także we wcześniej przesłanych czterech tomach wspomnień, zob. Ma-

teriały pamiętnikarskie..., R-651, s. 83-84.

12 Zob. Materiały pamiętnikarskie..., R-857, s. 99.

13 Ibidem, PTH R-112, s. 103. 
R-923

Augustyn Klimek ${ }^{14}$, Wspomnienia plebiscytowe, poszyt

Fragment Wspomnień plebiscytowych, 29 czerwca 1920 r. Zjazd Kół Śpiewaczych w Gietrzwałdzie, mps, form. A4, ss. 4; list Augustyna Klimka z 14 kwietnia 1960 r. do redakcji olsztyńskiego „Słowa na Warmii i Mazurach” dot. publikacji ww. wspomnień plebiscytowych, rkps, form. A4, ss. 1; odpis zaświadczenia podpisany przez Pawła Sowę, urzędnika Komitetu Plebiscytowego na Warmii z 19 września 1945 r. odnośnie do zaangażowania Augustyna Klimka w działalność polityczną i społeczną w czasie plebiscytu, form. A4, ss. 1; Wspomnienia plebiscytowe Augustyna Klimka za lata 1918-1920; praca nauczycielska w woj. poznańskim, wiec w Klebarku Wielkim; opis spotkania i korespondencja z Franciszkiem Kwasem; praca i działalność społeczna w szkole polskiej w Gietrzwałdzie; obchody 3 Maja; zaangażowanie w krzewienie polskości: ks. Jan Hanowski, organista Klatt; próby zastraszenia i przekupstwa autora wspomnień i odwiedzenia go od propolskiej działalności; postać Augustyna Henniga; Towarzystwo Gimnazjalne „Sokół”; manifestacja gietrzwałdzka - 29 czerwca 1920 r. Zjazd Kół Śpiewaczych w Gietrzwałdzie; postać Andrzeja Samulowskiego; nazwiska rodzin polskich zaangażowanych w akcję plebiscytową; skład komisji plebiscytowej; szkoły polskie w okresie plebiscytu, zamach Niemców na szkołę polską w Gietrzwałdzie; czerwiec 1957 i odsłonięcie tablicy pamiątkowej w Gietrzwałdzie, rkps, ss. 32.

\section{Nauczyciele szkół polskich na Warmii i Mazurach R-921}

Ankiety i pamiętniki nauczycieli szkół polskich, poszyt, mps, rkps, ss. 4+50 (19691970)

Pismo Dyrektora OBN Władysława Ogrodzińskiego z 8 grudnia 1969 r., zatytułowane Szanowny Panie, bez wskazania konkretnego adresata [z treści pozostałych dokumentów wynika, że chodzi o nauczyciela Kazimierza Gebela - A.D.], dot. przekazania do zbiorów OBN materiałów i dokumentów związanych z zagadnieniem szkolnictwa polskiego na Warmii, Mazurach i Powiślu w okresie międzywojennym oraz prośbę o wypełnienie ankiety, mps, form. A6, ss. 2; Imienna lista nauczycieli szkół polskich oraz wychowawczyń przedszkoli na terenie Warmii, Mazur i Powiśla w latach 1929-1939, mps, form. A4, ss. 3; Podziękowanie z 6 stycznia 1970 r., wypisane przez Dyrektora OBN Władysława Ogrodzińskiego dla nauczyciela Kazimierza Gebela za wypełnione ankiety, mps, form. B6, ss. 1; Odpowiedź Kazimierza Gebela na pismo odnośnie do ankiet, rkps, form. A5; Kazimierz Gebel (ur. 15 I 1896 r. w Śniatynie), w latach 1929-1938 nauczyciel w Szkole Powszechnej w Trzcianie, pow. Sztum, warunki pracy, uczniowie, rkps, form. A4, ss. 2; Wincenty Jabłonowski (ur. 15 VII 1905), dzieciństwo spędził w majątku Zybułtowo i w Adamowie w okolicach

14 Zob. Materiały pamiętnikarskie..., R-10, s. 19; R-261, s. 57-58; druk fragmentów wspomnień zob. A. Klimek, Wywiad z zapomnianym synem ziemi warmińskiej, „Słowo na Warmii i Mazurach”, nr 462-464 (6-8/1962), s. 3. 
Ostródy, zaangażowany w plebiscyt, w latach 1936-1945 mieszkał w Olsztynku, potem w następujących miastach: Olsztyn, Elbląg, Szczecin, rkps, form. A4, ss. 2; List Wincentego Jabłonowskiego do OBN z prośbą o potwierdzenie relacji jego i jego żony odnośnie do pobytu w Olsztynie dla Związku Bojowników o Wolność i Demokrację, rkps, form. A4, ss. 1; Leon Kauczor ${ }^{15}$ (ur. 11 IV 1910 r. w Strzeleczkach, pow. Krapkowice, woj. opolskie), w latach 1934-1937 nauczyciel w Staniszewie (Stanclewie), pow. Reszel; w latach 1937-1939 nauczyciel w Kwidzynie; pierwsze burzliwe dni w nowej szkole, relacje z miejscową ludnością (Polakami i Niemcami), folklor warmiński; Maria Kensbok (ur. 12 II 1917 r. w Purdzie, pod Olsztynem), uczęszczała do polskiej szkoły w Purdzie; w latach 1935-1939 wychowawczyni w polskim przedszkolu w Skajbotach, pow. olsztyński, w roku 1938 w nocy wybito szyby w jej mieszkaniu, członkini Związku Polaków, przeżyła wojnę w Skajbotach, rkps, form. A4, ss. 1; Pismo z 14 stycznia 1970 r. wysłane do Czesławy Lewandowskiej z Tczewa z podziękowaniem za wypełnienie ankiety, podpisane przez Władysława Ogrodzińskiego, mps, form. A5, ss. 1; Bogusław Lewandowski (ur. 2 III 1903 r. w Wielkim Mędromierzu), w latach 1930-1936 nauczyciel w Starym Kramsku, więzień obozu koncentracyjnego Mauthausen-Gusen; kwestionariusz wypełniła jego żona Czesława Lewandowska, rkps, form. A4, ss. 4; Bogusław Lewandowski, jw., druk ankiety, częściowo uzupełniony, wpisano posiadane odznaczenia; Pismo z Prezydium Powiatowej Rady Narodowej z Ostródy do Jerzego Kleszczyńskiego z dnia 29 lipca 1971 r. odnośnie do renty, mps, form. A4, ss. 1; Pismo Bohdana Koziełło Poklewskiego do Józefa Buzińskiego I Sekretarza KW PZPR z 10 września 1971 r. w sprawie działacza plebiscytowego Jerzego Kleszczyńskiego, mps, form. A4, ss. 3; Pismo do Ministerstwa Oświaty i Wychowania w Warszawie w sprawie podwyższenia renty specjalnej Maksymilianowi Modrzewskiemu z Iławy, mps, form. A4, ss. 3; Pismo Leokadii Szurek, z domu Musiał, skierowane do Okręgowego Muzeum Mazurskiego w Olsztynie z prośbą o informacje odnośnie do zaangażowania się jej ojca Jana Musiała w działalność plebiscytową, rkps, form. A4, ss. 3; Pismo Okręgowego Muzeum Mazurskiego do OBN z prośbą o zajęcie się sprawą Pani Leokadii Szurek, mps, form. A4, s. 1; Seweryn Piątek ${ }^{16}$ (ur. 23 X 1914 r. w Wielkim Buczku, pow. Złotów, woj. koszalińskie), nauczyciel w okresie międzywojennym w Nowej Kaletce, pow. Olsztyn; związany ze Związkiem Literatów w Olsztynie, rkps, form. A4, ss. 4; Konrad Sikora ${ }^{17}$ (ur. 3 XI 1902 r. w Gniewie, powiat Tczew, woj. gdańskie), w latach 1930-1933 nauczyciel w miejscowości Wymój, do 1 września 1939 r. nauczyciel we wsi Jaroty; dot. napaści dzieci ze szkół niemieckich na dzieci ze szkoły polskiej (pobicia, rzucanie kamieniami, wyzwiska); wizyta Melchiora Wańkowicza w szkole, hasła antypolskie, zrzucanie winy na polskiego nauczyciela za przejawy niemieckiej agresji wobec dzieci z polskiej szkoły; nazwiska mieszkańców wsi Jaroty, którzy doświadczyli agresji

15 Zob. list Leona Kauczora do Władysława Stachowskiego, Materiały pamiętnikarskie..., R-741, s. 89; PTH R-452 (nr 18), s. 116.

Zob. Materiały pamiętnikarskie..., PTH-R-452 (nr 23), s. 116. 
ze strony niemieckiej młodzieży (17-20 lat) w roku 1939; sierpień 1939 i napaść niemieckiej młodzieży na szkołę polską, nazwiska sprawców, wizyta w Jarotach redaktora „Gazety Olsztyńskiej” Seweryna Pieniężnego i dyrektora Banku Ludowego Juliana Malewskiego, mps, form. A4, ss. 3; Władysław Stachowski ${ }^{18}$ (ur. w Zakrzewie, pow. rawicki), w roku 1930 nauczyciel w Stanislewie (Stanclewie); zamiana nazwy wsi na niem. Sternsee, organizacja szkoły (pozyskiwanie uczniów i wyposażenia), uroczyste otwarcie szkoły 1 września 1930 r., listy uczniów, nauczane przedmioty, wizytacje niemieckich i polskich inspektorów, gwara warmińska, rola dyrektora niemieckiej szkoły w podżeganiu przeciwko mieszkańcom wysyłającym dzieci do polskiej szkoły, antypolskie hasła, Polacy zatrudnieni w niemieckiej szkole, rola miejscowego księdza w walce z polskością, organizacja niemieckiego przedszkola; prześladowania rodziców, którzy posyłali swoje dzieci do szkoły polskiej; spotkanie z Feliksem Nowowiejskim; dzień z życia w szkole; wizyta prof. dr. Kazimierza Nitscha z Krakowa i Augustyna Steffena, którzy prowadzili badania językoznawcze na Warmii; ludowe pieśni warmińskie zebrane w Stanislewie; konferencje nauczycielskie w Olsztynie; Dom Polski; język polski na Mazurach; relacje społeczne; Święto dziecka; nauczyciel Leon Kauczor; powrót do Stanislewa po wojnie, mps, form. A4, ss. 18; list Władysława Stachowskiego do OBN z 20 stycznia 1970 r., dot. przesłanych pamiętników i wspomnien, tu informacja o przygotowaniu do druku jego pamiętników i jego ucznia Ferdynanda Sosnowskiego, pt. Wspomnienia nauczyciela i ucznia ze Stanislewa ${ }^{19}$, rkps, form. A4, ss. 1; Odpis pisma Związku Polskich Towarzystw Szkolnych w Niemczech (Vorband Polnischer Schulvereine Deutschlands) z 16 grudnia 1932 r., skierowanego do Władysława Stachowskiego, dot. zwolnienia go z pracy w szkole w Stanislewie; podpisany przez prezesa Jana Baczewskiego, rkps, form. A4, ss. 1; Władysław Stachowski, ankieta, mps, rkps, form. A4, ss. 1; Piotr Taterra (ur. 19 X 1909 r.), w latach 1938-1939 nauczyciel wychowania fizycznego w Gimnazjum w Kwidzynie, ankieta, mps, rkps, form. A4, ss. 1; Pismo Związku Polskich Towarzystw Szkolnych w Niemczech z dnia 24 listopada 1931 do Jana Boenigka ${ }^{20}$, dot. zwolnienia ww. z obowiązków kierownika Towarzystwa Szkolnego na Warmię; brak podpisu prezesa, mps, form. A4, ss. 1; Pismo Związku Polskich Towarzystw Szkolnych w Niemczech z dnia 26 lutego 1931 r. do Jana Boenigka, dot. mianowania ww. na Komisarza Komisariatu „Mazowsze” Związku Polskich Towarzystw Szkolnych w Niemczech; brak podpisu prezesa, mps, form. A4, ss. 1.

R-977

Otylia Grot, Na ścieżkach mojego życia, mps, form. A4, ss. $175^{21}$

\footnotetext{
18 Por. Materiały pamiętnikarskie..., R-741, s. 89; O Władysławie Stachowskim zob. W. Stachowska-Dembecka, Władysław Stachowski. Życie i działalność 1899-1986, Poznań 2014.

19 Fragmenty wspomnień zostały opublikowane w: „Słowo na Warmii i Mazurach”, nr 274-278 (3438/1957)

20 Zob. Materiały pamiętnikarskie..., PTH R-452 (nr 15), s. 116.

21 Wspomnienia opublikowane zob.: O. Grot, Gdy zabrakło miłości, Olsztyn 1976 oraz O. Grot, W kręgu spraw ojczystych, Olsztyn 1982
} 
R-1013

Jadwiga Różycka, mps, form. A4, ss. 3

Z domu Barabasz, ur. 20 VII 1926 r. w Skajbotach; życiorys, córka Bernarda Barabasza, działacza plebiscytowego; członek Związku Polaków w Niemczech i Towarzystwa Młodzieży i Dzieci Polskich Szkół i Przedszkoli; pracownik Banku Ludowego w Olsztynie; odpis opinii z 19 stycznia 1972 r. wystawionej przez prezesa Wojewódzkiego Komitetu Zjednoczonego Stronnictwa Ludowego dr. Józefa Kijowskiego, form. A4, ss. 1.

R-1042

Kronika rodziny Walter, tłum. M. Anielska-Kołpa, form. A4, ss. 73

Maszynopis przygotowany na podstawie zeszytów prowadzonych przez Heinricha Augusta Waltera w latach 1904-1939, wraz z ich kontynuacją przez jego córkę Gertę do 29 lutego 1940 r.; Heinrich August Walter (ur. 23 II 1857 r.), nauczyciel w Średniej Szkole Żeńskiej (Töchterschule) w Olsztynie; dziadkowie, rodzice, dzieciństwo, najstarszy z ośmiorga rodzeństwa, czasy szkolne, Seminarium Nauczycielskie, od 6 maja 1876 r. nauczyciel w Suszu (Rosenberg), potem w Nowym Mieście (Neustadt), życie rodzinne, organizacja pracy w olsztyńskiej szkole, nauczyciele, I wojna światowa, codzienne zmagania i troski, zestawienia produktów spożywczych i cen, Królewiec i Berlin w latach 20. XX w., plebiscyt, życie codzienne, wycieczki po Prusach Wschodnich, rok 1939 i 1940 w Olsztynie.

R-1245

Augustyna Wiewiórzanka, Życiorys Augustyny Wiewiórzanki, rkps, k. 1, zał. k. 1 Ur. 22 IV 1900 r. w Bredynkach; nauczycielka szkół polskich; kurs nauczycielski w Olsztynie, seminarium nauczycielskie w Grudziądzu, praca w zawodzie, wybuch wojny i praca jako robotnik rolny, m.in. w Giznie, pracownik biurowy w Czarże, Stolnie, od marca 1946 r. kierownik szkoły w Dąbrowie Chełmińskiej, od 1 kwietnia 1946 r. kierownik szkoły we wsi Szynych koło Chełmna.

\section{3. „Dać świadectwo prawdzie” - konkurs i wywiady}

R-1113

Longin Dąbrowski, Z Komaszówki do Prus Wschodnich, mps, k. 19

Ur. w lipcu 1933 r. w Komaszówce; rodzinna wieś i dom, dzieciństwo, okupacja sowiecka, wywózki, Katyń, okupacja niemiecka, surowy rygor wojenny, wywózki na roboty przymusowe do Niemiec, bandy ukraińskie (nacjonaliści ukraińscy) i okrutne morderstwa, samoobrona Polaków - patrolowanie wsi itp., przeprowadzka do Dubna, warunki mieszkaniowe, relacje ze stacjonującym wojskiem niemieckim, głód, bandy młodzieżowych złodziei i przestępców, rok 1944 i polska szkoła w Dubnie, marzec 1945 r. repatriacja i podróż wagonami towarowymi (trasa Dubno-Brody-Lwów-Rawa Ruska-Rejowiec-Lublin-Warszawa-Działdowo-Neidenburg (Nidzica), organizacja życia na tzw. Ziemiach Odzyskanych, nadzieja na powrót do Wołynia, tęsknota za domem i poczucie tymczasowości w Nidzicy, nauka w szkole. 
R-1114

Anna Dropa, Szkoła w Świniarcu dziś..., rkps, ss. 3, zał. dok. 1

Ur. 10 IV 1945 r. we Lwowie; podróż do Tuszewa, pow. Nowe Miasto Lubawskie; szkoła w Świniarcu, organizacja nauczania, klasy, wyposażenie, warunki pracy i nauki.

$\mathrm{R}-1115$

A.R. ${ }^{22}$, Moje wspomnienia z Wołynia, rkps, zeszyt formatu A5, k. 43

Ur. w miejscowości Łózki, pow. Sarny, woj. wołyńskie; wołyńska przyroda, dzieciństwo, okupacja radziecka, lista rodzin na zesłanie, szkoła z językiem rosyjskim, luty 1940 r. masowe wywózki Polaków, podatki pieniężne, okupacja niemiecka, banderowcy, nacjonaliści ukraińscy, mordy i grabieże na Wołyniu, bandy UPA, opisy metod zadawania śmierci polskiej ludności - konkretne przykłady; akcje partyzantów, tułaczka po lasach, Białoruś - wieś Krasne, więzienie w Pińsku, relacje z miejscową ludnością, oddziały ukraińskich bojowników na Białorusi, koniec wojny, urzędnicy z Warszawy i namawianie do wyjazdu, karta ewakuacyjna.

R-1116

Leon Sawicki, Zdawałoby się to samo, a jednak inaczej widziane..., rkps, k. 20+7

Ur. w Wilnie; rodzina, 19 września 1939 r. obrona Wilna przed sowieckim najazdem przez młodzież akademicką i szkolną, konspiracja, od kwietnia 1940 r. prawo stałego pobytu tylko dla przybyłych na Wileńszczyznę przed rokiem 1920, działalność w AK, 14 września 1941 r. pierwsza pacyfikacja Żydów przy pomocy Litwinów, 27 września 1941 r. w Ponarach pod Wilnem Niemcy i Litwini rozstrzelali 320 Polaków, organizacja AK, zbrodnie dokonywane przez Litwinów za namową Niemców, prześladowania ludności polskiej i żydowskiej, działalność AK, oddział „Łupaszki”, losy poszczególnych oddziałów AK w latach 40. XX w.; dążenie Mazurów do autonomii, mazurscy działacze polonijni, odbudowa Szczytna, refleksje o powojennych losach tzw. Ziem Odzyskanych.

R-1117/1

Edward Studziński, Na bocznych torach ${ }^{23}$, mps, form. A4, k. 202

Noc z 10/11 lutego 1940 r., Wołowka, Polesie, przeszukiwanie domu, rewizja, transport wagonami bydlęcymi, Kazachstan, łagier, warunki mieszkaniowe i sanitarne, warunki i organizacja pracy, głód, choroby, śmierć rodziców; rok 1944 i wyjazd dzieci z łagru do schroniska w Pinedze (Pinega), opiekunowie, surowy rygor, rusyfikacja, przemoc wobec polskich dzieci, wysłannicy polscy w Pinedze, maj 1944 r., polska nauczycielka, prace wykonywane przez dzieci, choroby, głód, maj 1945 r. i podróż parostatkiem do Archangielska, droga na Kaukaz, Polski Dom Dziecka w Ipatowie, droga do Polski, PUR w Gostyninie. 
R-1118

Halina Szyszło, Wspomnienia, rkps, k. 11

Łuck, wrzesień 1939 r. i okupacja sowiecka, wywózki na Sybir, brak żywności, kolejki do sklepów, okupacja niemiecka, getto, bandy ukraińskie, wspomnienia dzieciństwa, Łuck w czasie wojny, 1945 r. i wyjazd do Polski, Działdowo, Ziemie Odzyskane, Olsztyn.

\section{R-1119}

Irena Żygas, Droga do kraju, mps, form. A4, k. 82

Ur. 20 VI 1933 r., z domu Wołk-Łaniewska; rodzina, dokumenty poświadczające szlachectwo, rodzinne majątki, zdjęcia, Mały Klarianów niedaleko Krzywic, Wileńszczyzna, życie codzienne, wybuch wojny, aresztowanie ojca, 10 lutego 1940 r. i deportacja, Syberia, Ural, miasteczko Diektiarka, warunki mieszkaniowe, sanitarne, głód i nędza, kopalnia rudy żelaza, formowanie się armii Andersa, rok 1943 północna Baszkiria - kołchoz „Czereuł”, insekty, praca, głód, szkoła polska, kołchoz „Zajcewo”, 17 marca 1946 r. i podróż do Polski, Lublin, zwiedzanie Majdanku, przesłuchania matki przez NKWD, zakaz mówienia o pobycie na Syberii, Wrocław, Pozarzecze.

mikrofilm, OMF 990/1

Kazimierz Guzik, mps, rkps, s. 32, 14 załączników w postaci ksero, odbitek i fotografii Jazłowiec na Podolu, jeden z czworga rodzeństwa, lata 30. XX w., Szkoła Rolnicza w Suchodole koło Krosna; 28 sierpnia 1939 r. nalot podczas wycieczki szkolnej, powrót na Podole, nastroje społeczne, relacje polsko-ukraińskie, konfiskata majątku i wywiezienie 16 polskich rodzin na stację kolejową w Buczaczu, 6 dni koczowania, życzliwość miejscowej ludności ukraińskiej, powrót do gospodarstwa; spisywanie majątku przez rosyjskich mundurowych - wg druków J. Curzytka; 10 lutego 1940 r. środek nocy - kolejna konfiskata majątku w obecności rosyjskiego wojska i wywózka nie do Buczacza, ale na Wschód do Czortkowa, Kopyczyńce, graniczny Husiatyn; wiersze i dziennik pisany przez matkę podczas wywózki i pobytu na Syberii; Muraszyn [Muraszi], Komi ASRR organizacja pracy, zaopatrzenie, nastroje, relacje między Polakami, Niemcami, Ukraińcami, Tatarami, stachanowcy, od czerwca $1941 \mathrm{r}$. problemy z zaopatrzeniem, racje żywnościowe dla pracujących, niedożywienie, głód; powiedzenia, wierszyki zasłyszane od innych grup ludności wraz z tłumaczeniem, warunki pracy, warunki atmosferyczne, praca w Kołchozie im. Siedemnastego Zjazdu Partii, relacje z miejscową ludnością, szczegółowe opisy domów, wyposażenia, jedzenia, zwyczajów.

Henryk Sawala, Myśmy z Miednik i Kaługi. Wspomnienia (1939-1946), mps, ss. 89, liczne załączniki: zdjęcia, dokumenty

Ur. 4 XII 1925 r. we Wronkach, woj. poznańskie; wrzesień 1934 r. i okupacja Wilna, NKWD, aresztowania, eksmisje, wywózki na Wschód, rewizje, kontrole mieszkań, problemy mieszkaniowe i z zaopatrzeniem, praca w gospodarstwie ogrodniczym, rok 1941 i okupacja niemiecka, powstanie getta, nauka zawodu mechanika i praca w „Herreskraftpark”, akcje sabotażowe, Tajne Komplety Nauczania, spotkania 
młodzieży, patriotyczne pieśni; konspiracja, AK grupa dywersyjno-rozpoznawcza, ps. „Poniatowski”; kolportaż prasy podziemnej, III Brygada Szczerbca, Kompania „Wiśni”, 7. Brygada „Wilhelma”, powstanie wileńskie, Miedniki Królewskie - sowiecki obóz, agitacja do wojska polskiego formowanego na Wschodzie, transport wagonami bydlęcymi, sytuacja w innych obozach i losy innych partyzantów; Kaługa, „dobrowolcy" - ochotnicy do Armii Czerwonej, umundurowany 361. pułk, praca w zniszczonym mieście i szkolenie wojskowe, życie obozowe; obóz Malejcha, praca i organizacja życia obozowego, listy pisane na korze brzozowej, działalność kulturalna, twórcza, obozowi artyści, sytuacja sanitarna; „fałszywa gruźlica” i wizyta u lekarza w Jegorewsku, powrót i zwiedzanie Moskwy, mauzoleum, Kirów, Brześć nad Bugiem, Biała Podlaska, UB.

Marta Indrunas, Wspomnienia z lat 1939-1945, rkps, zeszyt A5, kl. 21+1

Wspomnienia spisane na podstawie zapisek prowadzonych $w$ trakcie zesłania, załączniki szt. 5 (dokumenty, fotografie); Łuck, woj. wołyńskie, wybuch wojny, 28 sierpnia 1939 r. mobilizacja męża, oficera rezerwy do 24. pułku piechoty w Łucku; 1 września 1939 r. narodziny syna - Wiesława, ucieczka na wieś, zajęcie Łucka przez wojsko rosyjskie, służba porządkowa w rękach Ukraińców i Żydów; nauczycielka w szkole powszechnej w Łucku; mąż w obozie w Starobielsku, noc 13 kwietnia 1940 r. i deportacja, załadunek do bydlęcych wagonów; rozstanie z dziećmi, transport, „kipiatok” i „lura”, Kazachstan, selekcja pod kątem przydatności do pracy, ośrodek przymusowy Majkain-Zołoto; opis mieszkańców - Kazasi, Rosjanie, opis domów, warunki życia, wymiana produktów z miejscową ludnością, praca w kamieniołomach, przy fabrykacji cegieł, „wodowóz”; korespondencja z rodziną, paczki żywnościowe, warunki pracy („buran”), święta w obozie pracy, rok 1941 i problem z żywnością, brak korespondencji, choroby, od 1 czerwca 1942 r. nauczycielka w nowo powstałej polskiej szkole w Majkainie; lista produktów, które można było nabyć, mając tzw. zaborną książeczkę żywnościową, pobyt w Pawłodarze; praca w porcie jako ładowaczka soli, codzienne racje żywnościowe, od 11 października 1944 r. nauczycielka w polskiej szkole w Pawłodarze; list do Wandy Wasilewskiej i przepustka na wyjazd do Łucka dla dwóch osób, Łuck; pisząc te wspomnienia, autorka ma 81 lat i nadal żadnych wieści o swoim mężu.

Maria Wachowska, Opowieści babuni. Wołyniacy, rkps w formie zeszytu A5, kl. 25, załączniki: zdjęcia szt. 20 (fotokopie)

Wiersze o Wołyniu, rys historyczny Wołynia, rodzinna wieś Kopaczówka, koligacje rodzinne, dzieciństwo, rok 1939 widziany oczami dziecka, relacje z ludnością ukraińską i żołnierzami wojska sowieckiego, bezprawne aresztowania, konfiskata majątku, wywózki na Sybir, Katyń, Syberia, atak Niemców (24 VI 1941 r.) i wyzwalanie przez nich więźniów, Katyń; podpalenia, działalność UPA, polskie oddziały i placówki samoobrony, odwrót wojsk niemieckich i powrót Sowietów, masowe aresztowania, przymusowa deportacja na ziemie dawnych Prus Wschodnich, powroty Polaków na Wołyń i zsyłki na Syberię. 
Ryszard Dowgun, Wspomnienia Sybiraka, rkps w formie zeszytu A5, ss. 35, 2 załączniki Ur. 8 XII 1928 r. we wsi Winkowce koło Lidy, woj. nowogródzkie; 17 września 1939 r. deportacje Polaków na Wschód, propaganda, zakaz posługiwania się językiem polskim, palenie polskimi książkami w miejscowej piekarni, przybycie Niemców 24 czerwca 1941 r., mordowanie Żydów, księży, wywózki miejscowej ludności do Niemiec, działalność w AK, aresztowanie, metody przesłuchania, sąd, więzienie w Orszy, obóz koło Mohylewa, obóz „Szor” koło Uchty w Komi ASRR, praca przy wyrębie drzewa, warunki i organizacja pracy, warunki mieszkaniowe i wyżywienie, obóz „Dalnij”, rok 1948 i powrót do kraju, obóz w Brześciu nad Bugiem, PUR w Białej Podlaskiej, o pobycie $w$ obozie powiedział obcej osobie, sąsiadce, po raz pierwszy w 1956 r., sierpień 1971 r. i pobyt we Lwowie, świadek niszczenia cmentarza Orląt.

Witold Chitruszko, Informator pamiętnikowy z lat 1930-1965, rkps, form. A5, 1 zeszyt informacyjny, 3 zeszyty wspomnień i pamiętników, ss. 544, załączniki: zdjęcia szt. 18, dokumenty obozowe i dokumentacja z lat 60 . XX w. dotycząca ubiegania się o rentę od Związku Radzieckiego, listy od członków rodziny

Ur. 23 XII 1923 r. w Zapurnie koło Grodna; rodzina i dzieciństwo, gospodarstwo, okupacja sowiecka, okupacja niemiecka, członek AK pod dowództwem Józefa Łastowskiego, przymusowa praca w Niemczech, powrót w rodzinne strony 5 marca 1945 r.; działalność w AK, ps. „Jaskółka”, aresztowanie w lutym 1947 r., proces i droga na Syberię, obozy sowieckie na Syberii (1949-1958), tajszeckie obozy specjalne przeznaczone dla więźniów politycznych; obóz „Sosnowe Rodniki” No 233, praca w kopalni węgla w Kołymie, 15 stycznia 1952 r. wypadek w pracy i poważne uszkodzenie nóg, Białoruś i więzienie w Grodnie, Port Wanino, Tajszet i inne obozy; przyjazd do Olsztyna.

Witold Juszkiewicz, Dziecinny wyrok, rkps, k. 53

Mieszkał w Czechowcach koło Lidy; bardzo osobiste refleksje, ból wspomnień i zarazem radość, że wreszcie można mówić o sowieckich łagrach, „obozowa mafia”; walka w 77. pp armia "Prusy” jako st. strzelec z cenzusem; droga do Lwowa, prześladowania i mordy na Polakach, więzienie lwowskie, transport wagonami bydlęcymi, więzienie w Połtawie, Charków, łagry, Kandałaksza, praca w kamieniołomach, w łaźni jako palacz, relacje z innymi więźniami; Katłas i Peczera, przyjaźń z towarzyszem niedoli, Turkmenem, Workuta, pobyt w szpitalu, 1943 r. amnestia, brak pozwolenia na wyjazd, praca w Peczorach, od sierpnia 1943 r. w II Dywizji im. H. Dąbrowskiego.

Aurelia Raszkiewicz ${ }^{24}$, rkps, ss. 51, 8 załączników

Ur. 27 IX 1928 r. w Pińsku na Polesiu; wrzesień 1939 r. widziany oczami małego jedenastoletniego dziecka, najstarsza z czwórki rodzeństwa, wywózka bez rodziców, jedynie z dziadkami na Sybir, głód i choroba młodszego brata, racje żywnościowe, 
podróż przez Azję do Kungrad - Karakałpacka Republika Autonomiczna, praca przy zbiorze bawełny; Urgenez - Uzbekistan, kołchoz, praca przy zbiorze bawełny, sadzeniu ryżu itp., relacje z innymi Sybirakami, w tym z Niemcami, nauka języków i praca biurowa, codzienne radości i troski, opisy rodzimej ludności; Arlsk, Kazachstan, Sowchoz „Skalistyj”, głód i bieda, podróż pociągiem do Wandy Wasilewskiej, powrót 18 stycznia 1946 r., PUR w Nowej Soli, spotkanie z matką, Olsztyn.

Adam Jasiński, Wspomnienie - 50. rocznica wybuchu II wojny światowej, mps, ss. 6, załączniki: 4 fotografie

Pochodził z Wilna, walczył w oddziałach AK, 19. pułk artylerii lekkiej (d-ca ppłk Pichl), podoficer służby zawodowej w stopniu plut., walki pod Piotrkowem Trybunalskim, wkroczenie wojsk sowieckich, rozbrojenie i transport wagonami, wsypa, powrót na Wileńszczyznę.

Maria Rutkowska-Kupran, Przeżycie mojej rodziny w Zwiqzku Radzieckim, mps, ss. 5 Wileńszczyzna, okolice Naroczy, rodzina, rok 1948, ucieczka ojca przed sądem, aresztowanie piętnastoletniego brata Tadeusza, pobyt brata w Archangielsku, praca nauczycielki w wiosce pod Wilnem, wywózka matki i dzieci do kołchozu Kalinina w południowym Kazachstanie, miejscowość Głodny Step, relacje z miejscową ludnością i niemiecką; ojciec trafił do więzienia do Baranowicz, w ramach łączenia rodzin spotykają się w Kazachstanie.

Józef Rusakiewicz, mps, ss. 4

Wspomnienia spisała Maria Rutkowska-Kupran; ur. w Wołożynie, jedynak, nauka stolarstwa, praca w tartaku, ochotnik III pułku artylerii ciężkiej w Wilnie, stopień plut., VIII pułk artylerii ciężkiej, Chełm Lubelski, zwiadowca, odwrót w kierunku Lwowa, Baranowicze, aresztowanie, podróż wagonami bydlęcymi, więzienie, przesłuchania, obóz w Ostaszkowie, tłumacz, znał język rosyjski i białoruski, mieszkaniec Kętrzyna.

Jan Wincel, A jednak tak było. Wspomnienia i wrażenia z podróży i życia jako skazańca $w$ Syberii i powrotu do Polski $w$ drodze repatriacji 1 grudnia 1955, rkps, ss. 10 Wspomnienia w formie rymowanego wiersza; dzieciństwo w Józefowie na Wileńszczyźnie, praca w kołchozie, 25 marca 1949 r., konfiskata majątku i deportacja, Nowosady, Wilno, podróż wagonami, Lantworowo na Syberii, Czeremchowo nad rzeką Białą, praca przy wyrębie lasu, powrót, Lwów, Sącz.

Władysław Nowicki, Migawki z życia na Wileńszczyźnie w okresie 6-letniej II wojny światowej - 6-krotnej zmianie przynależności państwowej, mps, ss. 41

Ur. na Kaukazie; rys historyczny II wojny światowej z podziałem na sześć okresów: I. Rzeczpospolita Polska do 19 września 1939 r.: śmierć Piłsudskiego, wydarzenia polityczne do roku 1939, wybuch II wojny światowej - wydarzenia w Polsce; II. ZSSR 20 września - 27 października 1939 r.: działania wojenne; III. Republika Litewska 28 października 1939 - 15 czerwca 1940 r.: deportacje, antypolska działalność władz 
litewskich, działania wojskowe; IV. ZSRR 15 czerwca 1940 - 24 czerwca 1941 r.: sytuacja polityczna, Polacy na Wileńszczyźnie, atak Niemiec, Wilno po niemieckim ataku; V. Niemcy 24 czerwca 1941 - 12 lipca 1944 r.: los jeńców radzieckich, Żydzi, działalność w AK, wywózki na roboty do Niemiec; VI. ZSRR od 13 lipca 1944 r.: likwidacja AK, praca w Zarządzie Kolei Litewskich - Wydział Drogowy, gazeta Związku Patriotów Polskich „Wolna Polska”, Biuro Repatriacyjne w Wilnie, zima 1944 r. masowe aresztowania i wywózki na Wschód, śmierć gen. Czerniachowskiego, wyjazd do Polski.

mikrofilm, OMF 990/2

Ogłoszenie konkursowe „Dać świadectwo prawdzie”, mps, ss. 1

Albert Żebrowski, Wspomnienia z osiedlenia się na Warmii i Mazurach i poczqtkach pracy na kolei $w$ 1945-1946 roku, mps, ss. 15

5 maja 1945 r. przybył na Warmię i Mazury z Wilna jako repatriant, szczegółowy opis formułowania się administracji i sieci dyrekcji kolejowej w Olsztynie, kształcenie i werbowanie kadr do pracy na kolei, opis miasta, zaopatrzenie, kłopoty mieszkaniowe, pierwszy czynny odcinek kolei - Gutkowo-Orneta, uzyskane odznaczenia.

Józef Popławski, rkps, ss. 6

Ur. w roku 1928 w Wilnie, ojciec legionista, lipiec 1944 r., AK w okręgu wileńskim, łącznik AK II batalionu 85. pp, aresztowanie, obóz w Miedniku, transport wagonami bydlęcymi do Kaługi, wcielenie do 31. dywizji 361. zapasowego pułku piechoty, pierwszy szkolny batalion rota PTR, żołnierz armii radzieckiej, powrót do Wilna, opisał swoje przeżycia szesnastolatka po 45 latach milczenia; 7 stycznia $1945 \mathrm{r}$. aresztowany przez NKWD.

Leon Gackiewicz, mps, ss. 12

Ur. w roku 1923, mieszkaniec Wileńszczyzny; praca przy budowie lotniska w Rudominie, warunki bytowe, aresztowania, wywózki na Syberię, imienny wykaz zabitych w najbliższej okolicy, działalność w AK, areszt w Niemenczynie, proces, więzienie, łagier w Szyłutie, w okolicach Kłajpedy, łagier ASSP Mordowia, stacja Potma, praca przy załadunku drewna, praca przy wiązaniu sieci, nr w łagrze K 595, praca w kuchni, Omsk, praca przy budowie elektrowni, nazwiska towarzyszy niedoli, wypadek i pobyt w szpitalu, Pichtawka, sowchoz w Karolewce (Karolówka), praca na roli, poszukiwanie rodziny, droga do Polski.

Irena Moszczyńska, mps, ss. 8, 2 załączniki: Karta ewakuacyjna, Oświadczenie Ur. w roku 1926, z domu Bujko; jedna z czterech sióstr, styczeń 1945 r. dworzec, rampa tzw. Polezka, wywózka wagonami bydlęcymi na Syberię, wśród wywożonych brat autorki wspomnień (łagier w Donbasie), szczegółowy opis wydarzeń na dworcu, rok 1944 w Wilnie, więzienie AK-owców w Kałudze, masowe aresztowania, więzienie na Łukiszkach, wywózki w głąb Rosji, terror, bratu udało się uciec za czwartym razem z łagru i wrócił do Wilna, rok 1945 i Łódź, wspomnienia spisała po 44 latach. 
Bogusław Olgierd, Wygnańcy Ewy. Wspomnienia 1939-1946, mps, ss. 22, załącznik mapa, trasa tułaczki 1940-1946

Ur. w roku 1931 w Chełmnie nad Wisłą; syn oficera zawodowego (major), w roku 1938 całą rodziną przenoszą się do Pińska, Pińsk widziany oczami małego dziecka, wrzesień 1939 r. aresztowanie i wywiezienie ojca, rok 1940 wywózka wagonami bydlęcymi na Wschód, przez Brześć, Baranowicze, Borysów, Orsze, Smoleńsk, Moskwę, Kujbyszew, Czelabińsk, Pietropawłowsk, Kokczetaw, Aleksandrówka (Aleksandrowska stacja kolejowa Dżamantuz), relacje z miejscową ludnością, głód, choroby, praca przy budowie kolei, porcje żywnościowe, kurza ślepota, robactwo i insekty, Aktasta, praca przy budowie kolei, choroba, Osakarówka, praca na stacji pomp do przepompowywania wody, działalność Związku Patriotów Polskich - szkoły, rok 1946 powrót do ojczyzny, UNRRA, Brześć.

Bogusław Olgierd, Wygnańcy Ewy. Wspomnienia 1946-1954, mps, ss. 8, fotografie PUR w Brześciu, Chełmno, przydział mieszkania w Szczecinie i powrót do Chełmna, bezskuteczne ubieganie się o przyjęcie do sił zbrojnych, edukacja, Związek Młodzieży Polskiej, Liceum Techniczne Służba Polsce w Gryficach, spotkanie z kolegami z Pińska, praktyki, praca w Wydziale Komunikacji, rok 1952 i czynna służba wojskowa.

Aleksy Hempel, Wspomnienia więźnia z obozu internowanych w ZSRR, w latach 19441946, mps, s. 36, 3 załączniki

Ur. 2 II 1911 r., zamieszkały w Łukowie; właściciele ziemscy z Tuchowicza, rok 1944 i ucieczka Niemców, działalność w AK, praca w Ryżkach, aresztowanie przez NKWD, więzienie w Siedlcach, przesłuchanie, Sokołów Podlaski, transport wagonami bydlęcymi przez Łuków i dalej na Wschód, obóz Borowicze, stan osobowy obozu, wyposażenie, relacje między osadzonymi, racje żywnościowe, życie obozowe, szpital, łagier „Jegła lub Jogła”, praca przy wycince drzew, rok 1946 i powrót do kraju, Biała Podlaska, Tuchowicze, 497 dni nieobecności w domu rodzinnym.

Józef Pleban, Wspomnienie mieszkańca Kresów Wschodnich II Rzeczypospolitej po 1939 roku, mps, ss. 49

W roku 1939 zamieszkały w Rokitno Wołyńskie, ul. Ostoja nr 19, woj. wołyńskie; jeden z siedmiorga rodzeństwa; w roku 1935 rozpoczął pracę $w$ miejscowej hucie „Vitrum”, wojna zastała go w Częstochowie, aresztowanie, obozy jenieckie w Słowacji, obóz w Orem Laz, Komarom, Serbia (paszport jako Szyk Mariusz), podróż przez Grecję do Turcji, Palestyna, od 1941 r. służba wojskowa w Latrum, udział w obronie Tobruku i na froncie El Alamein w Afryce, udział w bitwie o Monte Cassino, walkach ruchomych nad Adriatykiem we Włoszech, życie, praca, nauka w Polsce Ludowej po powrocie z Anglii w 1947 r., Olsztyn.

Mieczysław Janczewski, Przeżyłem wojnę i pokój, spisane wspomnienia Grzegorza Węglickiego, $w$ formie rozmowy, mps, s. 37

Grzegorz Węglicki ur. w maju 1924 r.; Białoruś, majątek Marysin, rodzice, dzieciństwo, wrzesień 1939 r., luty 1940 r. i rewizja w domu, transport na Wschód, dziecięca 
ekscytacja podróżą, 45 dni podróży, Rosocha nad rzeką Szejngi; opisy przyrody, szkoła, choroby, wyżywienie i kartki na żywność, stachanowiec, armia radziecka (rok 1943), Archangielsk, starania o przyjęcie do polskiego wojska.

Narcyz Żarczyński, Wspomnienia kresowego szlachcica, mps, ss. 40

Wrzesień 1939 r., komunikaty radiowe BBC z Londynu, Związek Szlachty Zagrodowej, relacje między miejscową ludnością, Polakami, Ukraińcami, Żydami, obszerne cytaty z jakiejś książki, z której autor korzystał, ale jej autora ani tytułu nie podał, represje, deportacje na Wschód, 10 lutego 1941 r. deportacja Józefa i jego rodziny na Wschód - brat autora wspomnień, zapisy wspomnień brata, terror, NKWD, masowe groby więźniów, okupacja niemiecka, niemiecki obóz w Sarnach dla żołnierzy wojska sowieckiego, Równem, terror, nacjonalizm ukraiński, getto w Sarnach i jego likwidacja w lipcu 1942 r.; rok 1968 sąd odnośnie do zagłady Żydów w Sarnach, rozprawa w Bielsko-Białej i w Olsztynie - autor był świadkiem, ukrywanie żydowskiej dziewczynki, eksterminacja Polaków na Wołyniu w roku 1943; zabijanie przez ukraińskich partyzantów polskich rodzin, banderowcy, rok 1943 i zezwolenie na wyjazd do Generalnej Guberni, do Sambora.

Eligiusz Derencz, mps, ss. 15+1

Ur. w roku 1931, syn leśniczego, leśnictwo Balinka, podległe nadleśnictwu Krasne, 1 września 1939 r., noc 10 lutego 1940 r. rewizja przeprowadzona przez NKWD i deportacja bydlęcymi wagonami, podróż trwająca 6 tygodni; Pudźwa, Posiołek Czurocznaja, wyżywienie, głodowe porcje i choroby, warunki mieszkaniowe, kołchoz Staraja Bierozowa na Syberii, rok 1942 kadet w armii Andersa (grupa chłopców poniżej 17 roku życia), miejscowość Jagi-Jul i brytyjski mundur; Iran, Afganistan, Indie, Karaczi, Jamnagar, pobyt w szpitalu, polska szkoła, Valivade-Kolhapur i Polish Refugee Camp, International Refugee Organisation, rok 1948 i Afryka, Mombasa, obóz dla Polaków w Tengeru-Arusha, powrót do Polski, PUR w Międzylesiu, nauka w Liceum Ogólnokształcącym im. Adama Mickiewicza w Olsztynie, wezwanie do UB i podejrzenie o szpiegostwo.

Henryk Borkowski, rkps, s. $14+1$

Ur. w roku 1923 w podsiedleckiej wsi Krzesk; rok 1942 i wezwanie na roboty w Niemczech, ucieczka, działalność w AK, Bataliony Chłopskie - rejon Wiśniew, areszt i więzienie w Siedlcach; twierdza brzeska, transport wagonami bydlęcymi, Kusowo, między Orszą a Smoleńskiem, „syblag Morińsk”, racje żywnościowe, praca, życie obozowe, portrety Stalina, hasła propagandowe, ok. 30 różnych obozów, różne prace - od wyrębu lasu po stawianie pieców, powrót do kraju w kwietniu 1955 r., przesłuchanie przez UB, zakaz mówienia o pobycie na Syberii.

Leon Szarek, Jak zbłqkana ptaszyna, mps, ss. 28

Ur. w roku 1929; syn dyrektora szkoły, Halik, Polesie, komunikaty radiowe, okupacja radziecka i prześladowania polskiej ludności, aresztowanie i uwolnienie ojca; język białoruski i rosyjski w szkołach, deportacje na Wschód, listy z Syberii i Kazachstanu, 
terror NKWD, komunikaty radiowe, getto, powołanie ukraińskiej szkoły, założenie polskiej szkoły, walka o język i polską kulturę, czytanie książek, powołanie teatru, kultywowanie tradycji itp., Katyń, odwrót wojsk niemieckich, kopanie rowów dla Niemców, roboty przymusowe Belgia - Bruksela, sierpień 1945 r. decyzja o powrocie na Polesie, stacja Butzow i więzienie 11 września - 10 listopada 1945 r., podróż pociągiem przez Iławę, Olsztyn (obraz miasta), Insterburg (Wystruć), Mińsk, Drohiczyn Podlaski, rodzinny Halik, 23 marca 1946 r. i przybycie do Polski, Jędrzejów.

R-955

Relacje byłych mieszkańców Kresów Wschodnich, mieszkających w Olsztynie, poszyt, mps, rkps

Pismo Bohdana Łukaszewicza dot. przeprowadzenia wywiadów, mps, form. A4, ss. 1; Lista osób przeprowadzających wywiady, mps, form. A4, ss. 1; Kwestionariusz wywiadu, mps, form. A4, ss. 2

\section{R-955/1}

Helena Anders, mps, k. 15, dok. k. 5 (ksero)

Zeszyt z notatkami i poezją Bolesława Ławińskiego (dziadek autorki), k. 16 (ksero), zdjęcia (ksero) k. 1.

Ur. 1 V 1944 r., z domu Ławińska; Raputany, woj. wileńskie, wspomnienia spisane na podstawie opowieści rodziców, historia rodziny; 7 maja 1946 r. NKWD otoczyło dom, wysiedlenie, dwutygodniowy transport wagonami bydlęcymi z Wilna do Krasnojarskiego Kraju, Zawadowka, opis sąsiadów, warunki mieszkaniowe, praca przy wyrębie drzew, lata 50. XX w. budowa szkoły, relacje z miejscową ludnością, indoktrynacja, paczki z żywnością, opisy przyrody, łagry i więźniowie polityczni, bunt w łagrze w roku 1954, konspiracja, osiedleńcy, kołchoz, pionierzy, śmierć Stalina i radość w domu, odwiedziny brata na Syberii, oświadczenie o dobrowolnym przyjeździe na Syberię, rok 1956 i droga do Polski, gospodarstwo w Pasłęku, Olsztyn.

R-955/2

Stanisław Bondar, mps, form. A4, k. 21

Ur. 10 V 1926 r., mieszkaniec Wilna; terror, wywózki podczas okupacji rosyjskiej, okupacja niemiecka, więzień obozu w Postawach, w woj. wileńskim, ucieczka, żołnierz wileńskiej AK, areszt przez Rosjan i pobyt w więzieniu w Grodnie (1945 r.), kolejne więzienia Orsza, Smoleńsk, Łubianka, przesłuchania, tortury, obóz w Workucie, praca przy wycinaniu drzew, „Garbuszka”, normy chleba, „turneps”, warunki mieszkaniowe, organizacja obozu, praca na kolei, znajomość języka rosyjskiego środkiem na poprawienie doli, warunki sanitarne w obozie, łaźnie, koczownicze plemiona Komi, polowania na renifery, powstanie w kopalni w Workucie w roku 1947, praca w kopalni, rodzaje więźniów i los więźniów politycznych, amnestia 1948 r. i droga do Polski, Olsztyn w roku 1949, choroba, szpital, rok 1956 zatrzymanie i przesłuchanie przez UB, podsłuchy, donosy, odmowa paszportu. 
R-955/3

Józef Chitrowicz, mps, k. 14, zał. 2 dok. ksero

Ur. 19 III 1923 r. w Wilnie; okupacja radziecka i prześladowania Polaków, język rosyjski i litewski w szkołach; od roku 1941 wywózki na Wschód, okupacja niemiecka i masowe egzekucje, wywożenie na roboty do Niemiec, przymusowa praca dla Niemców w Słonimie; więzienie w Łukiszkach, prześladowania Polaków przez Litwinów, próba ucieczki do Polski w roku 1944 i zatrzymanie pod Grodnem, łagier w Uchcie nad Pieczorą, koczownicze plemiona Komi, warunki obozowe, normy pracy, praca przy budowie nasypów kolejowych, paczki, więźniowie: Rosjanie, Polacy, Niemcy, Żydzi, lipiec 1948 r. zwolnienie i droga do Polski, PUR Biała Podlaska, Warszawa, Łódź, Kraków, Koszalin, od sierpnia 1948 r. w Olsztynie, UB i przesłuchania, próby werbowania do współpracy.

\section{$\mathrm{R}-955 / 4$}

Anastazja Cichocka, mps, k. 6, dok. 2

Ur. 4 XII 1923 r. w Widzach, pow. Brasław, woj. wileńskie, z domu Lenartowicz; okupacja sowiecka i eksmisja z domu-leśniczówki, 10 lutego 1940 r. deportacja, droga na Syberię, transport wagonami bydlęcymi, tartak, warunki mieszkaniowe, praca przy wyrębie drzew, areszt ojca i więzienie w Tobolsku, Tobolsk i praca w domu dziecka, rok 1945 i przyjazd do Polski, PUR w Warszawie.

\section{R-955/5}

Tadeusz Dargiewicz, mps, k. 8, dok. 6

Ur. 8 VIII 1935 r., Porubanek, woj. wileńskie; 2 października 1951 r. aresztowanie rodziny (poza ojcem, który był nieobecny w domu), transport na stację, stacja towarowa Landtworów, podróż bydlęcymi wagonami (55 wagonów), Tomsk, Padgornaja, wymuszone podpisy pod oświadczeniami, że każdy dobrowolnie zgadza się na pobyt do końca życia, „posiołek Zawadzkaja”, praca przy odwszawianiu, jako stolarz, kowal, koniuszy, „obchodczyk wąskotorowej kolejki”, paczki, warunki mieszkaniowe, głód, opisy przyrody, brak elektryczności i dróg, zima 1955 r. informacja o drodze do Polski, lot samolotem, hotel, podróż pociągiem, PUR w Żurawicy, Olsztyn.

\section{R-955/6}

Anna Dramowicz, mps, k. 22

Ur. 24 IV 1919 r. w Pskowie, z domu Borowska; lipiec-sierpień 1939 r. pobyt na obozie Legii Akademickiej w Redłowie koło Gdyni, poczucie niechęci i wrogości ze strony Niemców, podróż do Wilna, nastroje młodzieży, 17 września 1939 r. i okupacja sowiecka, zwolnienia Polaków z pracy, prześladowania, zamknięcie Uniwersytetu Wileńskiego, zamykanie polskich szkół, 25 grudnia 1939 r. aresztowanie po mszy w kościele, śpiewała pieśń Boże, coś Polskę..., areszt w Wilnie, Szaki, zesłanie i praca jako pomoc ogrodnika w szkole „Riukszaj” w pałacu Potockiego, nauka języka litewskiego, powrót do Wilna, studia medyczne, stosunki na uczelni, nauczyciele, zajęcia, okupacja niemiecka i prześladowania Żydów, kartki na żywność, „Szaulisi” milicja litewska, praca w urzędzie gminy, praca w Arbeitsamt; wywózki na roboty do Niemiec, 
łapanki, aresztowana przez gestapo, Oran, obóz w Prawiniszkach pod Kolnem, życie obozowe, znajomość języka niemieckiego i litewskiego i praca w kancelarii, kwiecień 1944 r. i zwolnienie z obozu, powrót na studia, rok 1946 wyjazd do Polski, Łódź i dalsze studia.

R-955/7

Sławomir Dramowicz, mps, k. 4

Ur. 26 VIII 1911 r., osada Niemen, powiat nowogródzki; Lida, studiował filologię polską w Wilnie, ochotnik w wojsku, zwiad kolarski, więzienie w Piotrkowie Trybunalskim, uwolnienie i areszt w Radomiu, Lida, działalność partyzancka, akcja „Wilno”, ps. „Dzik”, łapanki, droga do Polski.

R-955/8

Edward Lachowicz, mps, k. 11

Ur. 13 X 1922 r.; Wilno, milicja złożona z Żydów i komunistów, zamknięte szkoły, praca na kolei, rok 1943 i wstąpienie w szeregi AK, brygada „Błyskawica”, ps. „Słowik”, potem „Kajtuś”, operacja wileńska AK, akcje partyzanckie - napadanie na pociągi, rozbrajanie czołgistów, nabór do armii Berlinga, Kaługa, praca przy wyrębie drzew, w kuchni, czerwiec 1945 r. i powrót do domu, droga do Olsztyna.

\section{R-955/9}

Franciszek Morawski, mps, k. 6, zał. dok. 2

Ur. 25 VIII 1910 r., Zwieraliszki, gmina Rzesza, pow. wileński, okupacja radziecka, podatki, milicja ludowa, partyzantka polska (ps. „Wilk”), litewska, ruska, w latach 1943-1946 aktywny w straży pożarnej, działalność NKWD, przypadkowy areszt i wywózka na Wschód wagonami bydlęcymi, warunki podróży, Krasnojarski Kraj, wieś Sołgon, Sowchoz „Bolszewik” w Sołgonie, znajomość języka rosyjskiego, praca jako kowal, relacje między więźniami, rok 1958 i amnestia.

\section{$\mathrm{R}-955 / 10$}

Wanda Mydło, mps, k. 16, dok. ksero k. 16 oraz zdjęcia

Ur. 17 X 1931 r., z domu Gosztowt, majątek Felin, Litwa kowieńska; rok 1939 i uciekinierzy z Polski na Litwie, okupacja sowiecka i stosunek Litwinów do Polaków, okupacja niemiecka i wywłaszczenie, rok 1945 ucieczka Niemców i powrót do rodzinnego majątku, rok 1946 lub 1947 wizy do Polski, tydzień przed wyjazdem rewizja i deportacja na Wschód wagonami bydlęcymi, Kamarczaga, pomoc miejscowych Polaków, Krasnojarski Kraj, racje żywnościowe, normy pracy dla dzieci, praca w lesie, warunki mieszkaniowe, listy na Litwę bez odpowiedzi, rok 1945 droga do Polski, PUR w Białej Podlaskiej, Olsztyn.

\section{R-955/11}

Irena Szmitkowska, mps, k. 6, dok. ksero k. 8 Ur. 28 VI 1932 r., z domu Zmitrowicz, zam. w Lidzie; aresztowanie całej rodziny w nocy z 20 na 21 czerwca 1941 r., trwająca miesiąc podróż wagonami bydlęcymi, 
warunki żywieniowe, sanitarne, Abakan, Jenisej i podróż statkiem, wieś Tigricko w minusińskim rejonie, w Krasnojarskim Kraju, choroby, nędza, bród, głód, jedyna polska rodzina, insekty, Minusińsko, Mała Minusa, dary UNRRA, ochronka dla polskich sierot, sześcioklasowa polska szkoła w Małej Minusie, warunki mieszkaniowe, stosunki Polaków z Białorusinami, wszechobecny głód, listy i paczki od rodziny, wiosna 1946 r. przyjazd do Warszawy i w tym samym roku do Olsztyna.

\section{$\mathrm{R}-955 / 12$}

Maria Tuliszewska, mps, k. 8

Ur. 25 XII 1922 r., z domu Malukiewicz; Krońki, pierwsze dni wojny, opis rosyjskich żołnierzy, konfiskata inwentarza przez wojsko, polskie ulotki, wywózki ludności, listy rodzin do wywózki, 17 czerwca 1940 r. ślub, nazwisko po mężu Mochnacz, polska i rosyjska partyzantka, działaczka AK, zaopatrzeniowiec i łączniczka (od roku 1942), w oddziale porucznika „Ostoi”, ps. „Popularna”, rok 1945 i ukrywanie się przed Rosjanami, sanitariuszka, 21 stycznia 1946 r. zatrzymana w Raduniu, przesłuchanie, oskarżona o bycie łączniczką Londynu, areszt w Grodnie, więzienie w Mińsku i sąd, Orsza, Estonia, Tallin, obóz żeński w Norylsku, praca przy budowie domów, nr obozowy 186; maj 1953 r. i strajk w obozie, 8 grudnia 1954 r. zwolnienie z obozu i lot samolotem do Krasnojarska, Moskwa, Wilno i problem ze znalezieniem pracy z powodu przynależności do AK; małżeństwo, przyjazd do Polski w roku 1957.

\section{$\mathrm{R}-955 / 13$}

Lech Woronkowicz, mps, k. 28, dok. kserokopie k. 5

Ur. 11 VII 1923 r. w Nowej Wilejce; 17 września 1939 r. w Wilnie, opis rosyjskich żołnierzy, przejęcie władzy w Wilnie przez Litwinów, obowiązkowa nauka języka litewskiego w szkołach, zmiana polskich nazwisk na litewskie - Woronkowiczijus, wymiana dokumentów, relacje z Żydami, okupacja niemiecka, siostry Magdalenki, konspiracja, powstanie wileńskie, areszt w Miednikach, werbowanie do armii Berlinga, transport wagonami bydlęcymi do Kaługi, racje żywnościowe, codzienne zajęcia, odmowa przysięgi, kołchoz Sieredniaki, praca w smolarni, praca przy wyrębie drzew, normy, listy, głód, insekty, choroby, paczki z UNRRA, ucieczki, grudzień 1945 r. i zwolnienie, droga wagonami towarowymi, dziesięciodniowy postój w okolicach Smoleńska, mundury angielskie, Brześć, Terespol, PUR w Białej Podlaskiej.

\section{Zakończenie}

Znaczną część materiałów wspomnieniowych, zgromadzonych w zbiorach biblioteki Ośrodka Badań Naukowych po 1985 r., stanowią teksty przesłane na konkurs „Dać świadectwo prawdzie”, skierowany do dawnych mieszkańców Kresów Wschodnich, jak również wywiady przeprowadzone z mieszkańcami Olsztyna, pochodzącymi z Kresów. Spośród materiałów konkursowych zachowało się siedem jednostek oraz dwa mikrofilmy, zawierające kolejno dwanaście i trzynaście relacji. Przeprowadzono trzynaście wywiadów z byłymi mieszkańcami Kresów Wschodnich, mieszkającymi w 1989 r. w Olsztynie. Zachowało się dziewięć uzupełnionych ankiet, wraz z dodatkowymi dokumentami, odesłanych przez byłych nauczycieli lub członków ich rodzin. Materiały będące uzupełnieniem wcześniej przesłanych tekstów to łącznie osiem jednostek. 
Przywołany materiał pamiętnikarski jest bardzo zróżnicowany nie tylko ze względu na treść. Występują tu zarówno wspomnienia (35), wywiady (14), ankiety (10), życiorysy (8), pamiętniki (2), wyciągi z kronik (2) oraz listy, lecz także pojedyncze opinie o działalności konkretnych osób. To zróżnicowanie wynika jednak nie tylko z ich formy, ale, co oczywiste, również z treści. Materiały te dotyczą przede wszystkim: doświadczenia II wojny światowej (prawie wszystkie teksty), w tym przymusowej migracji (jw.), Kresów Wschodnich (teksty nadesłane na konkurs i wywiady przeprowadzone z mieszkańcami Olsztyna, pochodzącymi z Kresów), ale też polskiego szkolnictwa na Warmii i Mazurach (ankiety rozesłane do dawnych nauczycieli) i plebiscytu (głównie wspomnienia nauczycieli). Różni je także perspektywa samych autorów. Mamy tu relacje i świat widziany oczami zarówno dzieci, jak i dorosłych ludzi, studiujących, pracujących, a nierzadko biorących udział w akcjach bojowych w trakcie II wojny światowej. Autorów dzieli nie tylko różnica wieku czy pochodzenie społeczne, ale również wykształcenie czy pełnione funkcje (np. nauczyciele, lekarze, rolnicy) itp. W każdym niemal przypadku mamy do czynienia z subiektywnym opisem wydarzeń i indywidualnych przeżyć.

Autorów, niezależnie od dzielących ich różnic, łączy doświadczenie przymusowej migracji, wojny, nierzadko cierpienie fizyczne i trud tułaczki, jak też tęsknota za utraconym domem. W zachowanych materiałach - spisywanych niekiedy po wielu latach - zwraca uwagę nagromadzenie szczegółowych, konkretnych informacji odnośnie do miejsc, osób, wydarzeń czy dat. Autorzy niejednokrotnie starali się uwypuklić wyjątkowość swoich losów. Nierzadko podkreślają ból, jaki sprawia im powrót pamięcią do przeszłości, i zarazem ulgę, że wreszcie mogą opowiedzieć o swoich przeżyciach, zwłaszcza tych dotyczących pobytu na Syberii, wieloletniej tułaczki oraz problemów w powojennej Polsce.

Do przesłanych tekstów załączano oryginalne dokumenty, wycinki prasowe, ulotki, kartki okolicznościowe, listy i fotokopie. Ta różnorodność i bogactwo nadesłanych materiałów sprawiają, że w wielu przypadkach wspomnienia autorów, wraz z licznymi załącznikami, stały się swego rodzaju teczkami osobowymi.

Nieliczne tylko wspomnienia i materiały pamiętnikarskie przechowywane w OBN doczekały się publikacji. Dotąd nie została zdigitalizowana omawiana część zasobu. 


\section{Bibliografia}

Januszkiewicz Z., rec., Materiały pamiętnikarskie w zbiorach Ośrodka Badań Naukowych im. Wojciecha Kętrzyńskiego, oprac. Z. Fras, „Informator Ośrodka Badań Naukowych im. W. Kętrzyńskiego w Olsztynie”, nr 37 (1986), „Komunikaty Mazursko-Warmińskie”, nr 33-36 (1-4/1989)

Klimek A., Wywiad z zapomnianym synem ziemi warmińskiej, „Słowo na Warmii i Mazurach”, nr 462 $464(6-8 / 1962)$

Materiały pamiętnikarskie w zbiorach Ośrodka Badań Naukowych im. Wojciecha Kętrzyńskiego, oprac. Z. Fras, „Informator Ośrodka Badań Naukowych im. W. Kętrzyńskiego w Olsztynie”, nr 37 (1986)

Ośrodek Badań Naukowych im. Wojciecha Kętrzyńskiego w latach 1988-1989. Sprawozdanie z działalności, Olsztyn 1990

Raszkiewicz A., Śladami ludzkich łez. Wspomnienia Sybiraczki, Olsztyn 1993

Stachowska-Dembecka W., Władysław Stachowski. Życie i działalność 1899-1986, Poznań 2014

Studziński E., Z Polesia do sowieckiego łagru, Wrocław 2012 


\section{Między historiq a pamięciq. Wspomnienia i pamiętniki w zbiorach biblioteki Ośrodka Badań Naukowych im. Wojciecha Kętrzyńskiego w Olsztynie (cz. 1)}

Streszczenie: Artykuł stanowi uzupełnienie inwentarza sporządzonego przez Zbigniewa Frasa (Materiały pamiętnikarskie w zbiorach Ośrodka Badań Naukowych im. Wojciecha Kętrzyńskiego, oprac. Z. Fras, „Informator Ośrodka Badań Naukowych im. W. Kętrzyńskiego w Olsztynie”, nr 37, Olsztyn 1986, ss. 148) o pamiętniki i wspomnienia dotyczące Kresów Wschodnich, doświadczenia II wojny światowej oraz szkolnictwa na Warmii i Mazurach w okresie międzywojennym i po II wojnie światowej, zgromadzone po 1985 r. w Zbiorach Specjalnych Biblioteki Ośrodka Badań Naukowych im. Wojciecha Kętrzyńskiego w Olsztynie. Znajdują się tu zarówno teksty będące uzupełnieniem wcześniej nadesłanych relacji, autorskie wspomnienia związane ze szkolnictwem polskim na Warmii, Mazurach i Powiślu, w tym również spisane na drukach ankiet rozsyłanych przez OBN do szkół. Odrębną grupę materiałów pamiętnikarskich stanowią prace nadesłane w 1989 r. na konkurs „Dać świadectwo prawdzie”.

\section{Between history and memory. Recollections and diaries from the collection of the library of the Wojciech Kętrzyński Academic Research Centre in Olsztyn (part 1)}

Abstract: Between history and memory. Recollections and diaries from the collection of the library of the Wojciech Kętrzyński Academic Research Centre in Olsztyn (part 1)

Abstract: This article represents the completion of the inventory drawn up by Zbigniew Fras (Diary materials from the collection of the Wojciech Kętrzyński Academic Research Centre, ed. Z. Fras, „Informator Ośrodka Badań Naukowych im. W. Kętrzyńskiego w Olsztynie”, 37, Olsztyn 1986, p. 148) concerning diaries and recollections relating to the Eastern Borderlands, experiences during the Second World War and education in Warmia and Masuria in the interwar period and after the war. These documents were collected after 1985 in the Special Collections section of the Wojciech Kętrzyński Academic Research Centre library in Olsztyn. The article also contains texts which add to previously submitted narratives, autobiographical recollections connected with Polish education in Warmia, Masuria and Powiśle, including those recorded in questionnaires sent to schools by the centre. This distinct group of diary materials is part of a 1989 submission to the "Testify to the Truth" competition.

Słowa kluczowe: inwentarz, pamiętniki i wspomnienia, Kresy Wschodnie, II wojna światowa, szkolnictwo na Warmii i Mazurach

Key words: inventory, diaries and recollections, Eastern Borderlands, Second World War, education in Warmia and Masuria 